ANDRADE JÚNIOR, VC; PEDROSA, CE; MIRANDA, TG; VALADARES, NR; PEREIRA, SL; AZEVEDO, AM. 2018. Biometric evaluation of morphoagronomic traits in pepper lines and hybrids. Horticultura Brasileira 36: 357-361. DOI - http://dx.doi.org/10.1590/S0102-053620180312

\title{
Biometric evaluation of morpho-agronomic traits in pepper lines and hybrids
}

\author{
Valter C Andrade Júnior ${ }^{1}$; Carlos E Pedrosa²; Thalita G Miranda ${ }^{3}$; Nermy R Valadares ${ }^{4}$; Samuel L Pereira ${ }^{3}$; \\ Alcinei M Azevedo ${ }^{4}$
}

${ }^{1}$ Universidade Federal de Lavras (UFLA), Lavras-MG, Brazil; valter.andrade@dag.ufla.br; ${ }^{2}$ Centro Universitário Una, Bom DespachoMG, Brazil; carlosenrrik@yahoo.com.br; ${ }^{3}$ Universidade Federal dos Vales do Jequitinhonha e Mucuri (UFVJM), Diamantina-MG, Brazil; thalitamiranda@yahoo.com.br; samuel.luan@hotmail.com; ‘Universidade Federal de Minas Gerais (UFMG), Montes Claros-MG, Brazil; nermyvaladares@hotmail.com; alcineimistico@hotmail.com

\begin{abstract}
In this study, we aimed to evaluate pepper lines and hybrids (Capsicum chinense and C. annuum) in order to obtain information on agronomic performance, heterosis, heterobeltiosis, phenotypic correlations and genetic dissimilarity. We evaluated lines PIM-030, BGH-433, BGH-4285, Numex Sweet, Numex Garnet and simple hybrids Numex Sweet x PIM-030, Numex Garnet x PIM-030 and BGH-4285 x BGH-433. The research was conducted with eight treatments and four replications in a greenhouse, at campus JK of UFVJM. Twenty two agronomic traits were evaluated. The hybrid BGH-4285 x BGH-433 presents higher heterosis and heterobeltiosis for total fruit productivity and productivity of total fruit dry mass, information of great value for future breeding studies. The authors noticed that larger plants tend to be more productive and present higher fruit fresh mass and also fruits with thicker pericarp, as well as larger fruits having longer pedicels with denser seeds, important for production of paprika. Lines BGH-433, BGH-4285 and PIM-030 are the most recommended to be used in breeding programs.
\end{abstract}

Keywords: Capsicum spp, breeding, heterosis, canonic variables, Mahalanobis distance.

\section{RESUMO}

Análise biométrica de caracteres morfoagronômicos em linhagens e híbridos de pimenta

Objetivou-se avaliar linhagens e híbridos de pimenta (Capsicum chinense e C. annuum) afim de obter informações sobre o desempenho agronômico, heterose, heterobeltiose, correlações fenotípicas e dissimilaridade genética. Foram avaliadas as linhagens PIM-030, BGH-433, BGH-4285, Numex Sweet, Numex Garnet e os híbridos simples Numex Sweet x PIM-030, Numex Garnet x PIM-030 e BGH-4285 x BGH-433. O experimento foi conduzido com oito tratamentos e quatro repetições, em casa de vegetação, no campus JK da UFVJM. Foram avaliadas 22 características morfoagronômicas. No híbrido BGH-4285 x BGH-433 foi observado maior heterose e heterobeltiose para produtividade total de frutos e produtividade de massa seca total de frutos, sendo interessante aos futuros programas de melhoramento. Observa-se que plantas de maior porte tendem a ser mais produtivas com maiores massas fresca dos frutos e frutos com pericarpo mais espesso, frutos maiores com maiores pedicelos e com sementes mais densas, sendo importante para a produção de páprica. As linhagens BGH-433, BGH-4285 e PIM-030 são as mais recomendadas para uso em programas de melhoramento.

Palavras-chave: Capsicum spp, melhoramento, heterose, variáveis canônicas, distância de Mahalanobis.

\section{Received on April 10, 2017; accepted on April 17, 2018}

$\mathrm{P}$ eppers of the genus Capsicum are known worldwide for its pungency, with a great variety of color and shape, being consumed in several ways. The genus also has important characteristics to produce condiments, such as flavor and aroma (Alves, 2015).

The species $C$. annuum presents a great deal of genetic variation, including sweet and spicy varieties, the species $C$. chinense is of great economic importance. Its diversity center is the Amazon basin region. Despite of the importance of these species, little information on morphological and productive traits, which meet industry needs, is available. As consequence, it is difficult to develop the industrial market, which is important for the national agriculture (Jarret \& Berket, 2012).

Some breeding programs have devoted efforts to obtain hybrids with resistance to diseases and superior agronomic traits (Fonseca, 2008), aiming to meet demands for fresh and processing consumption. Characterization of
Capsicum species is of great interest for germplasm banks, since the great variability is not completely described yet (Sudré, 2010). Thus, we conclude that characterizing Capsicum genotypes, in order to enhance genetic improvement and release new cultivar of the genus, is necessary.

The aim of this study was to evaluate lines and hybrids of pepper (C. chinense and $C$. annuum) aiming to obtain information on agronomic performance, heterosis, heterobeltiosis, phenotypic 
correlations and genetic dissimilarity.

\section{MATERIAL AND METHODS}

The experiment was carried out from August, 2011 to August, 2012, in campus JK at UFVJM, in Diamantina, MG. The local climate was classified as $\mathrm{Cwb}$, according to Köppen, characterized by mild and humid summers (October to April) and fresher and drier winters (June to August). Annual average rainfall ranging from 1,250 to $1,550 \mathrm{~mm}$ and annual average temperature from 18 to $19^{\circ} \mathrm{C}$, being mild all year long (Neves, 2005). Classification of the predominant soil is Orthic Quartzarenicenic Neossoil (Abreu et al., 2005). The authors performed chemical analysis of the soil of the greenhouse, where the experiment was installed and then the chemical fertilization was done (Casali \& Fontes, 1999).

Eight genotypes of Capsicum spp were evaluated, considering five lines and three hybrids. Two lines of $C$. chinense, from Germplasm Bank of Vegetables (BGH) of Universidade Federal de Viçosa, three lines of C. annuum provided by HortiAgro Sementes S.A., being PIM-030, pungent and red colored when ripe; Numex Sweet and Numex Garnet, varieties provided by Chile Pepper Institute of University of New Mexico (USA). The three simple hybrids were provided by HortiAgro Sementes SA: Numex Sweet $\mathrm{x}$ PIM-030 of $C$. annuum, being line Numex Sweet used as pollen source and emasculated line PIM-030, used as receptor; Numex Garnet x PIM-030 of C. annuum, being line Numex Garnet used as pollen source and emasculated line PIM-030, used as receptor; and BGH-4285 x BGH-433 of $C$. chinense, line BGH-4285 parents used as pollen source and emasculated line BGH-433, used as receptor.

On August 16, 2011, the genotypes were sown in polystyrene trays of 128 cells containing Plantmax substrate. Seedlings were kept on metallic banks until their transplantation. Seedlings with six to eight definitive leaves were transplanted in a greenhouse, in soil, in randomized blocks design with eight treatments (three hybrids and five lines) and four replications, totalizing 32 plots. Each plot consisted of eight useful plants, in two lines. The authors used spacing $0.70 \mathrm{~m}$ between plants and 0.85 between lines in seedbeds $1.00 \mathrm{~m}$ wide. Drip irrigation system was used, three times a day, and phytosanitary management done when necessary (Pinto, 2011).

During fructification, physicochemical characterization of the genotypes was carried out. For total fruit productivity $(\mathrm{t} / \mathrm{ha})$ the authors used data of weekly harvests, from March 9 to August, 23, 2012, totalizing fourteen harvests.

Evaluations of average fruit mass, number of seeds per fruit, pericarp thickness, fruit length, dry matter of pulp and dry matter of seeds (\%) were obtained using average of 20 fruits per plot. Height of the eight useful plants of the plot was measured using a measuring tape. To calculate the productivity of total dry mass of fruits, the authors divided percentage of dry matter of the fruit by total fruit productivity, being the results express in $\mathrm{t} / \mathrm{ha}$.

The authors used a software (R Core Team, 2013) for statistical analyses, and considered the model $\mathrm{Y}_{\mathrm{ij}}=\mathrm{m}+\mathrm{t}_{\mathrm{i}}+\mathrm{b}_{\mathrm{j}}+$ $e_{i j}$ in which: $Y_{i j}=$ observation in the $j$-th block, of the i-th genotype; $m=$ overall average of the variable in analysis; $t$ $=$ effect of the $\mathrm{i}$-th genotype $(\mathrm{i}=1,2$, ..., I); $\mathrm{b}=$ effect of the $\mathrm{j}$-th block $(\mathrm{j}=$ $1,2, \ldots, \mathrm{J}) ; \mathrm{e}_{\mathrm{ij}}=$ environmental effect of the ij-th plot. Using the variance components, the authors obtained coefficients of phenotypic, genotypic and environmental variation. ScottKnott grouping test at 5\% probability was used. Phenotypic correlation matrix was obtained through phenotypic averages of each treatment, and the significance of their estimates was obtained by $t$ test. For multivariate analysis, the authors performed graphic dispersion analysis of the first two canonical variables. Dissimilarity matrix of Mahalanobis' was also used in order to obtain grouping by Tocher's method.

\section{RESULTS AND DISCUSSION}

The authors observed significant differences among treatments using $\mathrm{F}$ test for all evaluated traits (Table 1).

Genetic correlation coefficient for total fruit productivity is below $47 \%$, showing less genetic variability for this trait, whereas for fruit fresh mass and fruit length the genetic variation coefficients were higher than 63 and $90 \%$, respectively.

Heterosis and heterobeltiosis for total fruit productivity were high for hybrid BGH-4285 x BGH-433, showing values 3.8 and 3.7 times higher, respectively, than the average of their parents, which showed lower productivities. The heterosis and heterobeltiosis reported in this study are essential traits for future breeding programs. Parentals showing low performance are able to produce hybrids with high degree of heterosis (Souza \& Maluf, 2003). High values of heterosis and heterobeltiosis could be reached due to the fact that the vigor of hybrid is directly related to the dissimilarity between parents and better adaptation of this genotype to weather conditions.

For percentage of seed dry matter, hybrid BGH-4285 x BGH-433 also showed positive heterosis and heterobeltiosis, which represent an increase in percentage of seed dry matter in the hybrid. Hybrid Numex Sweet $\mathrm{x}$ PIM-030 showed negative heterosis and heterobeltiosis, which makes impossible to use this hybrid in breeding programs. Dry seeds are sometimes added to the pericarp for making paprika, aiming to increase the quantity of the final product up to $25 \%$; however this procedure decreases color and quality (Mattos et al., 2008), thus the use of seeds should be reduced or avoided.

Only hybrids from line PIM-030 as a pollen receptor (Numex Garnet $\mathrm{x}$ PIM-030 and Numex Sweet x PIM-030) showed positive heterosis for pulp dry matter. For fruit dry mass, hybrids from line PIM-030 showed low heterosis, whereas hybrid BGH-4285 x BGH433 showed negative values for both traits. In relation to hybrid BGH-4285 $x$ BGH-433, some studies reported $70 \%$ of heterosis and values up to $234 \%$ of heterosis in crossing lines of C. chinense (Souza \& Maluf, 2003), highlighting the potential of this species 
for economic exploitation. For fruit fresh mass, all hybrids showed negative values for heterobeltiosis, showing a great reduction in fruit fresh mass when compared with more vigorous parents.

For total productivity of fruits, lines Numex Sweet, Numex Garnet, and the three hybrids, showed higher productivities. Considering 371 days of crop cycle, 164 days of harvest and 16,806 plants/ha, total productivity of fruits is higher than $20.14 \mathrm{t} / \mathrm{ha}$ for genotypes of $C$. chinense under protected cultivation in 105 days of harvest and 28,571 plants/ha (Souza \& Maluf, 2003), and productivity lower than $51.96 \mathrm{t} / \mathrm{ha}$ under protected cultivation considering stand of 16,667 plants/ ha in 224 days of cycle (Fontes et al., 2005). The differences between results are probably due to differences in stand, cycle and methodology used in this experiment, as well as in the conditions of temperature and luminosity.

Lines Numex Sweet, Numex Garnet and hybrid BGH-4285 x BGH-433 showed higher values of seed dry matter, showing, according to Carvalho \& Nakagawa (2000), high physiological maturation of these seeds. Differing from the others, the genotypes Numex Sweet and Numex Garnet showed higher values of fruit fresh mass. The genotypes $C$. annuum, such as Jalapeño and Cayenne, showed average mass per fruit from 45 to $60 \mathrm{~g}$ (Moreira et $a l ., 2006)$ and $C$. chinense showed great variability of average mass, from 0.1 to 22.7 g (Castro \& Dávila, 2008). Average mass of fruits showed genetic variability, higher than $90 \%$, ranging in studied genotypes among the species and in the same species.

Line Numex Sweet showed the thickest pericarp, similar to lines BGH4285, Numex Garnet and hybrid Numex Sweet x PIM-030, but different from the others (table 1). Pericarp thickness is related to fruit quality, considering that a cultivar which presents a thick pericarp, presents heavier fruits and with better post-harvest conservation (Blat et al., 2007).

Genotypes PIM-030 and hybrids Numex Sweet x PIM-030 and Numex Garnet x PIM-030 showed higher averages for number of seeds per fruits. In literature, accessions of $C$. аnпиит showing from 55 to 214 seeds can be found (Sudré, 2010). Genotypes $C$. chinense showed an average of 22.9 seeds per fruit. Souza \& Maluf, (2003), studying these same genotypes, noticed an average of 35.42 seeds per fruit. Great variation in number of seeds per fruits is observed, considering that the genotypes which show higher number of seeds per fruit are of greater interest to the seed production market.

Lines Numex Sweet and Numex Garnet showed the highest fruit length. For fruits of $C$. annuum, sizes ranging from $12.49 \mathrm{~cm}$ to $15.96 \mathrm{~cm}$ were reported (Blat et al., 2007). Evaluating accessions of 330 species of $C$. chinense

Table 1. Average clustering using Scott-Knott test for traits evaluated in pepper lines and hybrids. Diamantina, UFVJM, 2014.

\begin{tabular}{|c|c|c|c|c|c|c|c|c|c|c|c|}
\hline Parameters & PT & MSS & MSP & MFF & EP & NSF & CF & CP & AP & A1B & M100S \\
\hline \multicolumn{12}{|c|}{ Variation coefficients } \\
\hline Residual (\%) & 25.3 & 1.6 & 7.3 & 36.1 & 11.5 & 15.4 & 11.7 & 14.6 & 8.4 & 11.3 & 31.2 \\
\hline Genetic (\%) & 46.3 & 11.4 & 11.6 & 90.7 & 14.2 & 58.4 & 63.2 & 19.7 & 19.7 & 16.7 & 19.7 \\
\hline Relative & 1.8 & 7.0 & 1.6 & 2.5 & 1.2 & 3.8 & 5.4 & 1.4 & 2.4 & 1.5 & 0.6 \\
\hline \multicolumn{12}{|c|}{ Heterosis } \\
\hline $\mathrm{A} \times \mathrm{E}$ & 41.0 & -1.5 & 16.4 & -60.1 & -11.9 & 5.8 & -17.2 & -9.1 & 12.6 & 13.7 & 1.7 \\
\hline $\mathrm{B} \times \mathrm{C}$ & 385.4 & 29.5 & -1.2 & 6.9 & 4.7 & 35.6 & 0.5 & 5.0 & 18.6 & 4.2 & 44.0 \\
\hline $\mathrm{A} \times \mathrm{D}$ & 29.6 & -7.0 & 10.4 & -47.3 & -9.9 & 12.4 & -14.2 & -7.6 & 12.1 & 9.0 & -5.2 \\
\hline \multicolumn{12}{|c|}{ Heterobeltiosis } \\
\hline$A \times E$ & 22.9 & -4.3 & 1.0 & -69.9 & -16.2 & -10.7 & -33.7 & -10.4 & 8.6 & 11.9 & -8.8 \\
\hline $\mathrm{B} \times \mathrm{C}$ & 373.0 & 15.0 & -5.9 & -34.2 & -8.9 & 12.7 & -38.2 & -0.2 & -5.3 & -19.3 & 26.9 \\
\hline$A \times D$ & 4.1 & -10.2 & -6.0 & -59.4 & -20.4 & -4.8 & -33.0 & -11.4 & -0.1 & 2.1 & -23.3 \\
\hline \multicolumn{12}{|c|}{ Grouping } \\
\hline A - PIM-030 & $26.1 \mathrm{~b}$ & $51.1 \mathrm{c}$ & $4.1 \mathrm{~b}$ & $24.7 \mathrm{~b}$ & $2.0 \mathrm{c}$ & $121.8 \mathrm{a}$ & $12.1 \mathrm{~b}$ & $40.2 \mathrm{a}$ & $160.8 \mathrm{~b}$ & $29.6 \mathrm{a}$ & $1.0 \mathrm{a}$ \\
\hline B - BGH-433 & $9.7 \mathrm{c}$ & $48.7 \mathrm{~d}$ & $5.8 \mathrm{a}$ & $1.1 \mathrm{c}$ & $1.5 \mathrm{~d}$ & $25.7 \mathrm{c}$ & $1.4 \mathrm{e}$ & $27.5 \mathrm{~b}$ & $219.6 \mathrm{a}$ & $33.4 \mathrm{a}$ & $0.7 \mathrm{a}$ \\
\hline C - BGH-4285 & $9.2 \mathrm{c}$ & $37.7 \mathrm{e}$ & $6.4 \mathrm{a}$ & $4.5 \mathrm{c}$ & $2.1 \mathrm{c}$ & $17.0 \mathrm{c}$ & $6.1 \mathrm{c}$ & $24.8 \mathrm{~b}$ & $131.3 \mathrm{c}$ & $18.3 \mathrm{c}$ & $0.9 \mathrm{a}$ \\
\hline D - Numex Sweet & $43.0 \mathrm{a}$ & $54.9 \mathrm{~b}$ & $5.8 \mathrm{a}$ & $45.7 \mathrm{a}$ & $2.6 \mathrm{a}$ & $84.6 \mathrm{~b}$ & $21.6 \mathrm{a}$ & $43.9 \mathrm{a}$ & $125.7 \mathrm{c}$ & $25.9 \mathrm{~b}$ & $1.6 \mathrm{a}$ \\
\hline E - Numex Garnet & $35.1 \mathrm{a}$ & $54.2 \mathrm{~b}$ & $5.6 \mathrm{a}$ & $48.5 \mathrm{a}$ & $2.2 \mathrm{~b}$ & $83.9 \mathrm{~b}$ & $20.1 \mathrm{a}$ & $41.4 \mathrm{a}$ & $149.4 \mathrm{~b}$ & $30.6 \mathrm{a}$ & $1.3 \mathrm{a}$ \\
\hline $\mathrm{A} \times \mathrm{E}$ & $43.1 \mathrm{a}$ & $51.8 \mathrm{c}$ & $5.6 \mathrm{a}$ & $14.6 \mathrm{~b}$ & $1.9 \mathrm{c}$ & $108.8 \mathrm{a}$ & $13.3 \mathrm{~b}$ & $37.1 \mathrm{a}$ & $174.6 \mathrm{~b}$ & $34.3 \mathrm{a}$ & $1.2 \mathrm{a}$ \\
\hline $\mathrm{B} \times \mathrm{C}$ & $46.0 \mathrm{a}$ & $55.9 \mathrm{a}$ & $6.0 \mathrm{a}$ & $3.0 \mathrm{c}$ & $1.9 \mathrm{c}$ & $29.0 \mathrm{c}$ & $3.8 \mathrm{~d}$ & $27.5 \mathrm{~b}$ & $208.0 \mathrm{a}$ & $27.0 \mathrm{~b}$ & $1.2 \mathrm{a}$ \\
\hline $\mathrm{D} \times \mathrm{A}$ & $44.7 \mathrm{a}$ & $49.3 \mathrm{~d}$ & $5.5 \mathrm{a}$ & $18.5 \mathrm{~b}$ & $2.1 \mathrm{c}$ & $116.0 \mathrm{a}$ & $14.5 \mathrm{~b}$ & $38.9 \mathrm{a}$ & $160.6 \mathrm{~b}$ & $30.3 \mathrm{a}$ & $1.3 \mathrm{a}$ \\
\hline
\end{tabular}

Averages followed by same letter in the column did not differ significantly from each other, Scott-Knott, $\mathrm{p}<0.05$. $\mathrm{PT}=$ total productivity of fruits; $\mathrm{MSS}=$ seed dry mass; $\mathrm{MSP}=$ pulp dry mass; $\mathrm{MFF}=$ fruit fresh mass; $\mathrm{EP}=$ pericarp thickness; $\mathrm{NSF}=$ number of seeds per fruit; $\mathrm{CF}=$ fruit length; $\mathrm{CP}=$ pedicel length; $\mathrm{AP}=$ plant height; $\mathrm{A} 1 \mathrm{~B}=$ height of the 1 st bifurcation; $\mathrm{M} 100 \mathrm{~S}=$ mass of 100 seeds. 
length from 0.8 to $11.4 \mathrm{~cm}$ for fruit was already observed (Jarret, 2007). The size of the fruit ranges among species of genus Capsicum and in the species, which was possible to observe when studying these genotypes.

For pedicel length, hybrid BGH$4285 \times$ BGH-433 and its parental showed the lowest values, which can be a challenge to use these genotypes for production of hybrids intended for mechanized harvesting.

Highest plant heights were found in line BGH-433 and hybrid BGH-4285 $\mathrm{x}$ BGH-433, differing from the other genotypes. The plant should present a medium size (up to about $2.00 \mathrm{~m}$ ), if it does not affect its productivity, since it favors cultural practices and fruit harvest (Blat et al., 2007). The heights of BGH-433 and hybrid BGH4285 x BGH-433 were slightly above the ideal, according to literature cited, with exception of line BGH-433 and hybrid BGH-4285 x BGH-433, all the genotypes present satisfactory height for harvest.

Line BGH-4285 showed the lowest value of height in the first bifurcation, which is favorable, since the plant fructifies at each bifurcation, the lower the first bifurcation, the greater the productive potential of the offspring

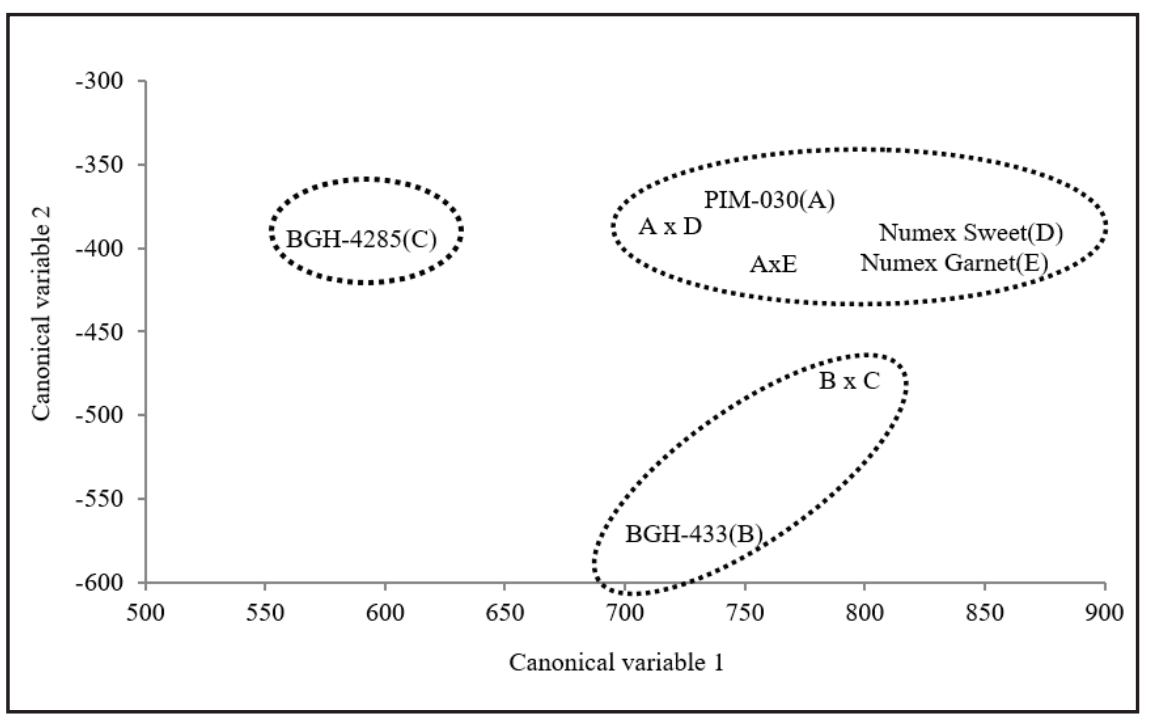

Figure 1. Graphic dispersion of the first two canonical variables for lines and pepper hybrids. The genotypes surrounded by dashed lines refer to the clusters formed by the Tocher method. Diamantina, UFVJM, 2014. tends to be.

Fruit fresh mass is positively related to pericarp thickness, fruit length and pedicel and to mass of 100 seeds, showing that plants with higher fresh production also show larger and thicker fruits (table 2). Thicker fruits present greater resistance to post-harvest damage, after being transported and, also, showing better appearance to be sold in natura. Positive correlation between fruit fresh mass and pericarp thickness had been already found in 49 accessions of $C$. chinense (Lannes et al., 2007).

Pericarp thickness is positively correlated with fruit length and negatively correlated with plant height, both with great magnitude. Plant height is also negatively correlated with fruit length. Thus, smaller plants present longer fruits with thicker pericarp, being considered interesting for papikra production. Positive correlation between fruit length and pericarp thickness was also found previously (Lannes et al., 2007).

Negative correlation between number of seeds per fruits and pulp dry mass was observed; however, the selection of genotypes with higher number of seeds will select indirectly fruits with lower percentage of pulp dry matter. Total productivity of fruits was positively correlated only with percentage of seed dry matter, which indicates that selection of more productive genotypes results in plants

Table 2. Pearson correlation matrix among phenotypic averages of traits evaluated in lines and hybrids of pepper. Diamantina, UFVJM, 2014.

\begin{tabular}{|c|c|c|c|c|c|c|c|c|c|c|}
\hline Variables & MSP & MFF & EP & NSF & CF & $\mathrm{CP}$ & $\mathbf{A P}$ & A1B & M100S & PT \\
\hline MSS & $-0.30^{\text {ns }}$ & $0.47^{\mathrm{ns}}$ & $0.21^{\mathrm{ns}}$ & $0.39^{\mathrm{ns}}$ & $0.41^{\mathrm{ns}}$ & $0.56^{\mathrm{ns}}$ & $0.26^{\mathrm{ns}}$ & $0.56^{\mathrm{ns}}$ & $0.56^{\mathrm{ns}}$ & $0.75^{*}$ \\
\hline MSP & & $-0.30^{\mathrm{ns}}$ & $0.01^{\mathrm{ns}}$ & $-0.73^{*}$ & $-0.26^{\mathrm{ns}}$ & $-0.56^{\mathrm{ns}}$ & $0.01^{\mathrm{ns}}$ & $-0.43^{\mathrm{ns}}$ & $-0.01^{\mathrm{ns}}$ & $-0.1^{\mathrm{ns}}$ \\
\hline MFF & & & $0.80^{* *}$ & $0.55^{\text {ns }}$ & $0.94^{* *}$ & $0.88^{* *}$ & $-0.63^{*}$ & $0.08^{\text {ns }}$ & $0.77^{* *}$ & $0.4^{\mathrm{ns}}$ \\
\hline EP & & & & $0.33^{\text {ns }}$ & $0.83^{* *}$ & $0.65^{*}$ & $-0.85^{* *}$ & $-0.42^{\text {ns }}$ & $0.87^{* *}$ & $0.42^{\mathrm{ns}}$ \\
\hline NSF & & & & & $0.70^{*}$ & $0.86^{* *}$ & $-0.32^{\mathrm{ns}}$ & $0.48^{\mathrm{ns}}$ & $0.49^{\mathrm{ns}}$ & $0.54^{\mathrm{ns}}$ \\
\hline $\mathrm{CF}$ & & & & & & $0.92^{* *}$ & $-0.71^{*}$ & $0.1^{\mathrm{ns}}$ & $0.85^{* *}$ & $0.54^{\mathrm{ns}}$ \\
\hline $\mathrm{CP}$ & & & & & & & $-0.5^{\mathrm{ns}}$ & $0.36^{\mathrm{ns}}$ & $0.75^{*}$ & $0.57^{\mathrm{ns}}$ \\
\hline AP & & & & & & & & $0.55^{\text {ns }}$ & $-0.57^{\mathrm{ns}}$ & $-0.07^{\mathrm{ns}}$ \\
\hline A1B & & & & & & & & & $-0.06^{\mathrm{ns}}$ & $0.29^{\text {ns }}$ \\
\hline M100S & & & & & & & & & & $0.79^{\text {ns }}$ \\
\hline
\end{tabular}

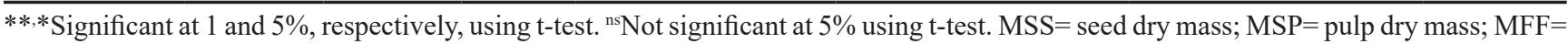
fruit fresh mass; $\mathrm{EP}=$ pericarp thickness; $\mathrm{NSF}=$ number of seeds per fruit; $\mathrm{CF}=$ fruit length; $\mathrm{CP}=$ pedicel length; $\mathrm{AP}=$ plant height; $\mathrm{A} 1 \mathrm{~B}=$ height of 1 st bifurcation; $\mathrm{M} 100 \mathrm{~S}=$ mass of 100 seeds; $\mathrm{PT}=$ total fruit productivity. 
with higher contents of seed dry matter, considering interesting to an increase in the quantity of material in order to produce papikra.

Evaluating graphic dispersion of canonical variables (Figure 1) is possible to highlight lines and hybrids in three different groups using the grouping method of Tocher, considering lines BGH-4285 and BGH-433 and hybrid BGH-433 x BGH-4285; and the third group which consisted of lines PIM030, Numex Sweet and Numex Garnet, hybrids which presents line PIM-030 as one of the parentals. Using this analysis, the authors could conclude that lines BGH-433, BGH-4285 and PIM-030 are the most recommended ones for breeding programs, aiming to obtain a great deal of genetic variation of the evaluated variables in this study. Low values of heterosis were found for the hybrids from the crossing between lines PIM-030 and Numex Sweet or Numex Garnet. Lines Numex Sweet and Numex Garnet, due to genetic similarity with line PIM-030, should be avoided in breeding programs that already have the latter line, since little genetic gain is expected when it is used.

\section{ACKNOWLEDGEMENTS}

The authors thank to CAPES, CNPq and FAPEMIG for financial assistance and for the scholarship granted to develop this study and to HortiAgro for providing the seeds.

\section{REFERENCES}

ABREU, PAA; SILVA, AC; PEDREIRA, LCVSF. 2005. Geologia. In: SILVA, AC; PEDREIRA, LCVSF; NASCIMENTO, LB; WACHLEVSCKI, M; LEITE, F; ABREU, PAA (eds). Serra do Espinhaço Meridional Paisagens e Ambientes. Diamantina: UFVJM. p.17-44.

ALVES, SRM. 2015. Pré-melhoramento em Capsicum: identificação de espécies hibridação interespecífica e variabilidade genética em caracteres de semente. Manaus: UFAM. 116p (Ph. D. thesis).

BLAT, SF; BRAZ, LT; ARRUDA, AS. 2007. Avaliação de híbridos duplos de pimentão. Horticultura Brasileira 25: 350-354.

CARVALHO, NM; NAKAGAWA, J. 2000. Sementes: ciência, tecnologia e produção. Jaboticabal: Funep. 590p.

CASALI, VWD; FONTES, PCR. 1999. Pimentão. In: RIBEIRO, AC; GUIMARÃES, PTG; VENEGAS, VHA(eds). Recomendações para o uso de corretivos e fertilizantes em Minas Gerais $5^{\circ}$ aproximação. Viçosa: UFV. p.95-96.

CASTRO, SP; DÁVILA, MAG. 2008. Caracterización morfológica de 93 accesiones de Capsicum spp del banco de germoplasma de La Universidad Nacional de Colombia - Sede Palmira. Acta Agronómica 57: 247-252.

FONTES, PCR; DIAS, EN; SILVA, DJH. 2005. Dinâmica do crescimento, distribuição de matéria seca e produção de pimentão em ambiente protegido. Horticultura Brasileira 23: 94-99.

FONSECA, RM, LOPES, R; BARROS, WS; LOPES, MTG; FERREIRA, FM. 2008. Morphologic characterization and genetic diversity of Capsicum chinense Jacq. accessions along the upper Rio Negro Amazonas. Crop Breeding and Applied Biotechnology. 8: 187-194.
JARRET, RL. 2007. Morphologic variation for fruit characteristics in the USDA/ ARS Capsicum L. germplasm collection. HortScience 42: 1303-1305.

JARRET RL; BERKET, T. 2012. Variation for fruit morphological characteristics in a Capsicum chinense Jacq. Germplasm collection. HortScience 43: 1694-1697.

LANNES, SD; FINGER, FL; SCHUELTER, AR; CASALI, VWD. 2007. Growth and quality of Brazilian accessions of Capsicum chinense fruits. Scientia Horticulturae 112: 266-270.

MATTOS, LM; MORETTI, CL; HENZ, GP; SOUSA, RMD. 2008. Caracterização póscolheita de espécies de Capsicum spp. Revista em Agronegócios e Meio Ambiente 1: 179-186.

MOREIRA, GR; CALIMAN, FRB; SILVA, DJH; RIBEIRO, CSC. 2006. Espécies e variedades de pimenta. In: PINTO, CMF; SILVA, DJH. Informe Agropecuário Cultivo da pimenta. Belo Horizonte: EPAMIG. p. 16-29.

NEVES, SC. 2005. Fisiografia. In: SILVA, AC; PEDREIRA, LCVSF; NASCIMENTO, LB; WACHLEVSCKI, M; LEITE, F; ABREU, PAA. Serra do Espinhaço Meridional Paisagens e Ambientes. Diamantina: UFVJM. p.45-60.

PINTO, CMF. 2011. Cultivo da pimenta (Capsicum spp.). In: RÊGO, ER; FINGER, FL; RÊGO, MM. Produção, Genética e Melhoramento de Pimentas (Capsicum spp). Recife: Imprima. p.51-60.

R DEVELOPMENT CORE TEAM. 2013. R: A language and environment for statistical computing. $R$ Foundation for Statistical Computing, Vienna, Austria. Available at http:// http://www.R-project.org. Accessed November 25, 2013.

SOUZA, JA; MALUF, WR. 2003. Diallel analyses and estimation of genetic parameters of hot pepper (Capsicum chinense Jacq.). Scientia Agricola 60: 105-113.

SUDRÉ, CP. 2010. Genetic variability in domesticated Capsicum spp. as assessed by morphological and agronomic data in mixed statistical analysis. Genetics and Molecular Research 9: 238-294. 